\title{
Awareness, Knowledge, Attitudes, and Behaviors of the Parents of 9-18 Year-Old Children About HPV Infection and HPV Vaccine in a Developing Country
}

\author{
9-18 Yaş Grubu Çocuğu Olan Ebeveynlerin HPV Enfeksiyonu ve Aşısı Hakkında \\ Farkındalık, Bilgi, Tutum ve Davranışlarının Değerlendirilmesi
}

\author{
Pınar Çelik'(iD), Sonay İncesoy Özdemir²(iD) \\ ${ }^{1}$ Health Center Family Medicine Unit, T.C. Health Ministry, Çorum, Turkey \\ ${ }^{2}$ Division of Pediatric Oncology, Department of Pediatrics, Ankara Yıldırım Beyazıt University Faculty of Medicine, Ankara, Turkey
}

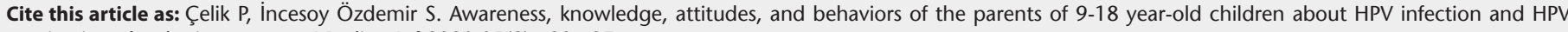
vaccine in a developing country. J Pediatr Inf 2021;15(2):e80-e87.

Abstract

Objective: Since licensure of the human papillomavirus (HPV) vaccine, HPV vaccine coverage among Turkish adolescents has remained low compared with other recommended vaccines. The aim of this study was to determine parents awareness, knowledge, attitude and perceptions about HPV infection and HPV vaccine in Turkey. This information is critical to the development of approaches to optimise HPV vaccine uptake among this population group.

Material and Methods: A descriptive cross-sectional study was carried out between September 2017 and February 2018. The study sample comprised of volunteering to the families of children aged 9-18 years that were evaluated at Ankara Yıldırım Beyazıt University Yenimahalle Training and Research Hospital Clinic of Pediatrics. A total of 1000 parents participated in this study. The survey sought socio-demographic characteristics of their families, the level of knowledge about HPV infection and vaccination, attitudes and behaviors on vaccination practice.

Results: 762 (76.2\%) women and 268 (26.8\%) men were included in this study. The mean age was $37.7 \pm 6.4 .66 \%$ of the mothers were graduates of high school and university, while $80.2 \%$ of the fathers were graduates of high school and university. Only 269 (26.9\%) of the parents had heard of HPV and 220 (22\%) had heard of HPV vaccine. The most common source of information of parents was the print media organs. Only 55 $(5.5 \%)$ of the parents reported that they were informed by pediatrician and family physician. Only $14(1.4 \%)$ of the parents were vaccinated for HPV. Only two parents had their children get vaccinated against HPV.
Öz

Giriş: İnsan papilloma virüsü (HPV) aşısının ruhsatlandırılmasından bu yana, ülkemizde adölesanların HPV aşılanma oranları, önerilen diğer ücretli aşılara kıyasla daha düşük kalmıştır. Çalışmamızın amacı 9-18 yaş aralığındaki çocukların ebeveynlerinin HPV enfeksiyonu ve aşısı hakkında bilgi düzeyi, tutum ve davranışlarını öğrenmektir. Bu çalışmanın sonuçları, ülkemizde HPV aşılanma oranlarını iyileştirmeye yönelik yaklaşımların geliştirilmesi için önemlidir.

Gereç ve Yöntemler: Ankara Yıldııım Beyazıt Üniversitesi Yenimahalle Eğitim Araştırma Hastanesi Çocuk Polikliniklerine başvuran 9-18 yaş çocukların aileleriyle gönüllülük esas alınarak, anket çalışması şeklinde yürütülmüştür. Ankette ailelelerin sosyo-demografik özellikleri, HPV enfeksiyonu ve aşısı hakkındaki bilgi düzeyleri, aşıyı uygulama konusundaki tutum ve davranışları sorgulanmıştır. Çalışmaya toplam 1000 ebeveyn katılmıştır.

Bulgular: Çalışmaya katılanların 762 (\%76.2)'si anne, 238 (\%23.8)'i baba idi. Yaş ortalamaları $37.7 \pm 6.4$ idi. Annelerin 503 (\%66)'ü lise ve üniversite mezunuyken, babaların 191 (\%80.2)'i lise ve üniversite mezunudur. Ebeveynlerin yalnızca 269 (\%26.9)'u HPV enfeksiyonu ve 207 (\%20.7)'si HPV aşısı hakkında bir şeyler duymuş/okumuştu. Bilgi edinme kaynakları arasında birinci sırada basın yayın organları, ikinci sırada ise hekimler vardı. Ebeveynlerin yalnızca 55 (\%5.5)'i çocuk doktorundan ve aile hekiminden bilgi edindiğini belirtmiştir. Ebeveynlerden yalnızca 14 (\%1.4)'ü kendisine HPV aşısı yaptırmıştı. Çocuğuna HPV aşısı yaptıran ebeveyn sayısı yalnızca ikiydi. Araştırmaya katılan ebeveynler HPV enfeksiyonu ve aşısı hakkında sınırlı bilgiye sahipti. 
Conclusion: Despite the good socioeconomic status and accessible health care services of our sample, their awareness and knowledge about $H P V$ infection and HPV vaccine was very low.

Keywords: Human papilloma virus, HPV vaccine, child, Turkey

\section{Introduction}

Human Papiloma Virus (HPV) infection is a major health problem worldwide. HPV infection which is sexually transmitted to both male and female is a global epidemic. Most of the HPV infections are asymptomatic and transient, however, symptomatic infection may result in genital (most commonly associated with HPV serotypes 6 and 11) or cervical, penile, anal warts, and several can lead to high-grade lesions and eventually to HPV-associated cancers.lt is estimated that about 530.000 new cases of invasive cervical cancer were diagnosed worldwide in 2013, and an estimated 270.000 women died of this disease (1).

In recent years, the most important strategy for the prevention of HPV infection and associated diseases is the primary prevention, which includes both elimination of sexual risk factors and vaccination. HPV vaccines are recommended to individuals from both genders between 9-26 years of age worldwide and before the first sexual experience. There are three types of HPV vaccines: the 9-valent vaccine (Gardasil 9) which protects against HPV types $6,11,16,18,31,33,45,52,58$, the quadrivalent vaccine (Gardasil) which protects against HPV types $6,11,16,18$, and the bivalent vaccine (Cervarix) which protects against HPV types 16 and 18 only. In recent years a number of countries have rolled out national HPV vaccination programs for girls, and, more recently, boys (2-3). But, it is not included in Turkey's national immunization programme. The cost, potential side effects of HPV vaccine and suspicious vaccine safety and negative news on all vaccines prevent the generalization of HPV vaccination (4). In order to prevent these, not only the healthcare workers but also parents should have the necessary and sufficient knowledge about HPV infection. It is important to determine the current levels of knowledge, awareness, attitudes to provide the necessary trainings and carry out awareness studies on this subject.

The purpose of this study is to determine the level of knowledge, attitude, and behaviors about HPV infection and vaccination from parents of children aged 9-18 years.

\section{Materials and Methods}

This study was approved by the Medical Research Ethics Committee of Yıldırım Beyazıt University with the number of $2017 / 25$. The study was designed as cross-sectional and descriptive. The study included 1000 volunteering parents with children aged 9-18 years who were admitted to the pediatric
Sonuç: Olumlu sosyoekonomik koşullara ve ulaşılabilir sağlık hizmetlerine sahip örneklem grubumuzda dahi, HPV enfeksiyonu ve aşısı hakkında farkındalığın düşük olması ülke genelinde sonuçların daha olumsuz olduğunu düşündürmektedir.

Anahtar Kelimeler: İnsan papilloma virüs, HPV aşısı, farkındalık, Türkiye

outpatient clinics in Ankara Yıldrım Beyazıt University Yenimahalle Training and Research Hospital between September 2017 and February 2018. Only the mother or father of a child was interviewed. The inclusion criteria were as follows: 1 ) being older than 18 years old, 2) having at least one child between the ages of 9-18,3) volunteering to participate in the study.

\section{Study Instrument}

The questionnaire form used for data collection was developed by the researchers after reviewing the literature. A pilot study was conducted on 10 volunteers in order to evaluate the feasibility and comprehensibility. No changes were made in the questionnaire form following the pilot study. The study questionnaire included open and closed questions. The questionnaire form consisted of three parts. In the first part, in addition to general sociodemographic variables (age, sex, residency, education level, marital status, number of child, employment, income and family history of cervical cancer), the questionnaire also enquired into parents knowledge and behaviours concerning vaccines (whether the optional vaccines were known, which optional vaccines had been administered, source of information and relevant factors). In the second part of the questionnaire, whether the parents previously heard/knew about HPV infection and HPV vaccine, and if yes, from which source they obtained this information and whether they were previously vaccinated for HPV were questioned. In this part, the questionnaires of the individuals who answered no to the question about hearing /knowing about HPV infection and HPV vaccine were terminated. The third part of the questionnaire was administered to the individuals who answered yes to any of the items of HPV infection or HPV vaccine. In the third part of the questionnaire, the knowledge of the individuals about HPV infection and HPV vaccine was questioned with a sentence including 24 statements about HPV infection and HPV vaccine. They were asked to respond to these sentences by choosing one of the options of "true, false, don't know". As this part was not a scale assessment with its current status, the answers of the individuals were evaluated separately for each statement. In the last section of the third part of the questionnaire, the opinions of the individuals about HPV infection and HPV vaccine were questioned with a sentence including thirteen different statements. The individuals were asked to answer as "agree, disagree, no idea". In this part, each sentence was evaluated individually. 


\section{Statistical Analysis}

The statistical analyses were performed using the SPSS v.15 (Statistical Package for the Social Sciences, Chicago, IL, USA). In the study, numerical data were expressed as mean and standard deviation, and categorical data were shown as frequency and percentages. The chi-square test was used for categorical data. In all statistical analyses, a $p$ value of $<0.05$ was considered statistically significant.

\section{Results}

\section{Demographic Data of the Parents}

The study population consisted of $238(23.8 \%)$ males and 760 (76\%) females with a mean age of $37.7 \pm 6.4$ years for both males and females. 306 (30.6\%) of the parents in our sample had an educational level of primary and secondary school, and 694 (69.4\%) had an educational level of high school and university. Of the mothers, 503 (66.0\%) were high school and university graduates and 191 (80.2\%) of the fathers were high school and university graduates. Of the parents, 524 (52.4\%) were employed, 476 (47.6\%) were unemployed. The majority of the unemployed group consisted of mothers. 456 mothers were unemployed. The income of 215 (21.5\%) parents was less than their expenditure, the income of the 642 (64.2\%) parents were equal to their expenditure and the income of 143 (14.3\%) parents were higher than their expenditure. Of the study population, 964 (96.4\%) did not have a family history of cervical cancer. The distribution of the sociodemographic characteristics of the parents are presented in Table 1.

\section{HPV Infection and HPV Vaccine Awareness}

Of the parents included in the study, 269 (26.9\%) had heard/read about HPV infection and 220 (22\%) had heard/ read about the HPV vaccine. The awareness about HPV vaccine was higher in mothers (22.0\%) than in fathers (17.0\%) $(p=$ 0.038 ). The high school and university graduate parents were highly aware of HPV vaccine $(p<0.001)$. The rate of hearing/ knowing about HPV vaccine was higher in the parents who previously had their children get any optional vaccine than in the parents who did not previously had their children get any optional vaccine, which yielded a statistically significant correlation between them $(p<0.005)$. The awareness of the parents who were healthcare personnel was high $(p<0.001)$. Family history of cervical cancer did not affect the awareness of parents about HPV infection and vaccine $(p=0.62)$.

\section{Attitudes Regarding HPV and Other Optional Vaccination}

Of the parents, 198 (19.8\%) had their children inoculated with any optional vaccine not included in the national immunization programme. Rotavirus $(n=76,7.6 \%)$ and meningococ $(n=31,31.0 \%)$ were mostly implemented vaccines. There were only $2(0.2 \%)$ parents who had their children inoculated with HPV vaccine. There were only 14 (1.4\%) parents who were vac- cinated against HPV. When we questioned the reasons why parents did not have their children get any optional vaccine, $480(48.0 \%)$ parents stated that they did not approve the vaccines not included in the national immunization programme. Of the parents, $255(25.5 \%)$ reported that they were not informed by pediatrician and $263(26.3 \%)$ reported that they were not informed by family physician.

\section{Information Acquisition Sources}

Of the parents included in the study, 220 (22\%) had heard/ read about the HPV vaccine. When the information acquisition sources of the parents who were aware of HPV vaccine were evaluated, it was found that of the parents, $84(8.4 \%)$ were informed by written and visual media, 62 (6.2\%) by gynecologists and obstetricians, 59 (5.9\%) by social environment, 41 (4.1\%) by family physician, 14 (1.4\%) by pediatrician and 37 (3.7\%) were informed by other health professionals (One parent can report more than one source).

\section{Knowledge and Opinions on HPV Infection and Vaccine}

The third part of the questionnaire was administered to the individuals who answered yes to any of the items of HPV infection or HPV vaccine. Of the parents, 220 responded this part by which we questioned the knowledge about HPV infection

Table 1. Baseline characteristic of parents

\begin{tabular}{|l|c|c|}
\hline & $\mathbf{n}$ & $\%$ \\
\hline Gender & & \\
$\quad$ Female & 762 & 76.2 \\
$\quad$ Male & 238 & 23.8 \\
\hline Age & & \\
25-35 & 385 & 38.5 \\
36-45 & 488 & 48.8 \\
46-65 & 127 & 12.7 \\
\hline Educational Level & & \\
Primary and secondary school & 306 & 30.5 \\
$\quad$ High school and university & 694 & 69.5 \\
\hline Income & & \\
Income less than expenditure & 215 & 21.3 \\
Income higher than expenditure & 642 & 64.2 \\
Income equal expenditure & 143 & 14.3 \\
\hline Working Status & & \\
Yes & 524 & 52.4 \\
$\quad$ No & 476 & 47.6 \\
\hline Job & & \\
Health personnel & 136 & 13.6 \\
Education personnel & 85 & 8.1 \\
Other & 779 & 77.9 \\
\hline Number of children & & \\
1 & 293 & 29.3 \\
2 & 487 & 48.7 \\
3 and above & 218 & 21.8 \\
\hline Family history of cervical cancer & \\
Present & 36.6 \\
Absent & & \\
\hline
\end{tabular}


Table 2. The level of knowledge of the parents about HPV infection

\begin{tabular}{|c|c|c|c|}
\hline HPV infection; & Yes, n (\%) & I don't know, n (\%) & No, n (\%) \\
\hline HPV is spread by women only & $86(8.6)$ & $39(3.9)$ & $93(9.3)$ \\
\hline HPV is spread by men only & $16(1.6)$ & $71(7.1)$ & $131(13.1)$ \\
\hline HPV is spread through by airway & $32(3.2)$ & $86(8.6)$ & $100(10.0)$ \\
\hline HPV is spread through by blood & $100(10.0)$ & $77(7.7)$ & $42(4.2)$ \\
\hline HPV is spread through sexual relationship & $172(17.2)$ & $40(4.0)$ & $8(0.8)$ \\
\hline HPV causes cervical cancer & $164(16.4)$ & $52(5.2)$ & $3(0.3)$ \\
\hline HPV causes genital warts & $118(11.8)$ & $82(8.2)$ & $19(1.9)$ \\
\hline There is no method of protection from HPV infection & $23(2.3)$ & $68(6.8)$ & $128(12.8)$ \\
\hline HPV vaccine can protect against HPV infection & $144(14.4)$ & $63(6.3)$ & $13(1.3)$ \\
\hline The risk of HPV infection increases when numbers of sexual partner increase & $103(10.3)$ & $85(8.5)$ & $31(3.1)$ \\
\hline HPV infection can be prevented by using medication & $33(3.3)$ & $142(14.2)$ & $44(4.4)$ \\
\hline HPV infection is not a serious infection that requires vaccination & $11(1.1)$ & $71(7.1)$ & $137(13.7)$ \\
\hline
\end{tabular}

Table 3. The level of knowledge of the parents about HPV vaccine

\begin{tabular}{|c|c|c|c|}
\hline HPV vaccine; & Yes, n (\%) & I don't know, n (\%) & No, $n(\%)$ \\
\hline Only for married women & $19(1.9)$ & $76(7.6)$ & $124(12.4)$ \\
\hline Sexually active anyone can be vaccinated & $121(12.1)$ & $84(8.4)$ & $14(1.4)$ \\
\hline HPV vaccine was not found in the national vaccination program & $80(8.0)$ & $125(12.5)$ & $14(1.4)$ \\
\hline HPV vaccine can protect against cervical cancer & $142(14.2)$ & $74(7.4)$ & $3(0.3)$ \\
\hline The HPV vaccine is not protective & $15(1.5)$ & $95(9.5)$ & $109(10.9)$ \\
\hline
\end{tabular}

of individuals who heard of HPV infection from any source. Of the parents who answered the questions, $86(8.6 \%)$ thought that HPV infection was seen only in females, $16(1.6 \%)$ thought it was seen only in males, and $91(9.1 \%)$ thought it was seen in both males and females. While there were 172 (17.2\%) individuals who knew that HPV infection is sexually transmitted, there were 164 (16.4\%) individuals who knew that HPV infection causes cervical cancer. Of the parents who participated in the study, 23 (2.3\%) thought that there was no way to protect against HPV infection, while 144 (14.4\%) knew that they could be protected by vaccination (Table 2 ).

There were 219 parents who responded to the part by which the knowledge about HPV vaccine was questioned. Of these parents, $67(6.7 \%)$ knew that HPV vaccine could be administered to girls and boys above 9 years of age. Of these parents, 142 (14.2\%) knew that HPV vaccine was protective against cervical cancer (Table 3 ).
Of the parents who heard/knew about HPV vaccine, 90 (9\%) stated that they found the vaccine reliable and 81 (8.1\%) stated that they approve to get HPV vaccine. Of the parents, $65(6.5 \%)$ found the vaccine expensive, $63(6.3 \%)$ did not approve to get vaccines other than those included in the national immunization programme, 19 (1.9\%) found unnecessary to get HPV vaccine, 16 (1.6\%) stated that the vaccine was harmful, and $11(1.1 \%)$ stated that the vaccine was not consistent with their religious values. The number of parents who believe that the vaccine will increase polygamy is $18(1.8 \%)$ (Table 4 ).

\section{Discussion}

This is the largest study to determine parental knowledge, attitude and behaviour towards HPV infection and HPV vaccine in Turkey. We demonstrated that a large number of parents living in the capital city of Turkey did not have sufficient knowledge about HPV infection/vaccine and the rates of HPV vaccination were very low. 
Table 4. Parents attitudes regarding HPV vaccination and barriers to vaccination

\begin{tabular}{|c|c|c|c|}
\hline & $\begin{array}{l}\text { Agree } \\
\mathrm{n}(\%)\end{array}$ & $\begin{array}{c}\text { No idea } \\
\text { n (\%) }\end{array}$ & $\begin{array}{c}\text { Disagree } \\
\text { n (\%) }\end{array}$ \\
\hline I want my children vaccinated against HPV infection & $93(9.3)$ & $103(10.3)$ & $19(1.9)$ \\
\hline The family physician did not inform me enough about the HPV vaccine & $45(4.5)$ & $51(5.1)$ & $119(11.9)$ \\
\hline Vaccination of children against HPV infection is correct & $81(8.1)$ & $110(11.0)$ & $24(2.4)$ \\
\hline HPV vaccine is unnecessary & $19(1.9)$ & $86(8.6)$ & $110(11.0)$ \\
\hline HPV vaccine is harmful & $16(1.6)$ & $99(9.9)$ & $100(10.0)$ \\
\hline HPV vaccine is not appropriate for my religious beliefs & $11(1.1)$ & $56(5.6)$ & $148(14.8)$ \\
\hline HPV vaccine may be increase the number of sexual partners & $18(1.8)$ & $63(6.3)$ & $134(13.4)$ \\
\hline
\end{tabular}

We examined year 2013 census data (Turkey Demographic and Health Survey) to determine limitations in the generalizability of our results. Although we oversampled mothers who did not work outside the home, our sample was better than census data in terms of maternal employment. The employment rate of the mothers in our sample was $40 \%$, while this rate is $31 \%$ across Turkey. In addition, the rate of individuals with high school and university education is $33.4 \%$ across the country, while it was $69.5 \%$ in our study. Sixty-six point two percent of the mothers and $80 \%$ of fathers had an educational level of high school and university. The educational and employment status of the parents was also higher than the overall Turkish population. These results indicate that the knowledge of the parents about HPV infection/vaccine and the rates of HPV vaccination may be even lower in less educated general population of Turkey (5). Our sample group had additional advantages besides high socioeconomic level. Most important of these is that they live in Ankara, the capital city of our country where healthcare services are provided in the best conditions.

Awareness has an important place in health behaviors, and awareness-raising studies in preventive health services are especially important. One of the main reasons for low HPV vaccination rate is the lack of awareness in this area. In a study by Onan et al. (6) on 1808 female participants in our country, of the participants, only $24.8 \%$ stated that they have heard of HPV infection, while $24 \%$ stated that they have heard of HPV vaccine. In various studies reported from the USA, it ranged from $49 \%$ to $91.7 \%(7,8)$. In our study, the rate of those who were aware of HPV infection was $26.9 \%$, while the rate of those who have heard of HPV vaccine was $22 \%$. Both rates are lower than those reported in the international literature. However, it is parallel with other studies conducted in our country. This result is of importance in terms of showing the lack of awareness studies on HPV infection and vaccine in our country. In our study, we found that the educational levels and HPV vaccine awareness of the parents were related but the income level of the parents was not associated with the HPV vaccine awareness. Moreover, in our study, there was no difference between those with and without a family history of cervical cancer in terms of levels of awareness. Even the presence of a family member with cervical cancer, one of the leading cancers caused by HPV, did not raise the awareness of the individuals. It was concluded that there is a need to accelerate awareness studies on the subject in schools or visual-verbal media.

The US Centers for Disease Control and Prevention and the American Academy of Pediatrics recommend every adolescent aged 11-12 years to get vaccinated for HPV. In our study, the rate of the parents who had their children vaccinated was $0.2 \%$. In a 2015 study by Reagen-Steiner et al. on 20,000 adolescents in the USA, the rate of HPV vaccination was $42 \%$ in boys and 60\% in girls (9). In a 2011 study by Al-Naggar et al. on 612 individuals in Malaysia, it was found that the rate of having at least one dose of the vaccine in female adolescents aged $13-17$ years was $77.9 \%$ (10). This rate was $64.8 \%$ in a study conducted in Japan, $59.8-94.4 \%$ in different studies conducted in the UK (11-13). When the scientific literature was reviewed, the lowest vaccination rates were reported as 3.3\% in a 2015 study in Lithuania and $2.4 \%$ in a study in Hong Kong $(14,15)$. In our study with a sample size of 1000 individuals, it was found that only $2(0.2 \%)$ parents had their children get vaccinated. This rate is lower than all the studies in the literature. Considering that the majority of the study group (92.5\%) lived in urban areas and in the capital of the country, this rate is 
quite low. The reason why $19.5 \%$ of the parents had their children get any other optional vaccine but not the HPV vaccine can be explained by the low level of awareness in this respect. When the reasons of the parents for not having any optional vaccination are examined, the most common reason was not being in the national vaccination schedule. Many countries have included the HPV vaccine in their national vaccination schedule. In Australia, the HPV Immunisation Program was conducted between 2007 and 2009, and by 2009, 70\% of adolescents aged 12-17 years were vaccinated (16). Such national vaccination policies have a great impact on vaccination. We can say that our country needs a national program to increase the rates of HPV vaccination.

In the literature, it was emphasized that some sociodemographic characteristics related to the development of vaccination behavior may also be effective. In a systematic review conducted by Fisher et al., it was shown that socioeconomic status has a limited effect on attitudes regarding the HPV vaccine. In addition, it is reported that individuals who are not covered by health insurance have low vaccination rates in the USA (17). Although the vaccines are administered within the scope of health programs in Denmark, it was observed that there was a relationship between socioeconomic level and vaccination rate (18). On the other hand, it has been observed in some studies that less-educated individuals were more easily convinced to have vaccination $(10,19)$. In a study conducted in Hong Kong, it was found that as the education level of mothers increased, the rates of vaccination for their children increased (20). In our study, the factors related with the vaccination rate could not be evaluated statistically since the vaccination rate was very low.

When the sources of information acquisition of the parents about the vaccines were reviewed, it was found that the written and visual media were in the first place, the information obtained from the obstetrician was in the second, and the information obtained from the social environment was in the third place. Only 55 (5.5\%) of the parents stated that they obtained information from the pediatrician and family physician. First of all, it is of great importance that the sources of information acquisition are reliable. It is known that the information obtained from physicians is evaluated to be more reliable in the studies investigating patient perceptions in this respect. In a 2014 study by Quinn et al. (21), it was found that physicians do not recommend HPV vaccine to individuals. When the studies are reviewed carefully, it can be said that the most important reason for needing doctor's advice is the concerns of individuals about the safety of the vaccine $(22,23)$. As in many countries in the world, it is observed in Turkey that there is a significant perception that vaccines may have serious side effects and they are not reliable. Physicians have an important responsibility to overcome negative attitudes and behaviors against vaccination. One of the first steps to be taken is to measure the attitudes and behaviors of physicians or health professionals about the subject.

When the knowledge levels of parents are evaluated; only 16.4\% knew that HPV infection could cause cervical cancer and only $14.4 \%$ knew that the vaccine could provide protection. In addition, of the parents only $1.6 \%$ knew that both males and females could be infected with HPV, $11.8 \%$ knew that it could cause genital warts, and $10.9 \%$ knew that the vaccine was protective. In numerous studies, it has been preferred to ask separate questions aiming to measure key information instead of using valid and reliable scales to measure the level of knowledge, as we did in our study. In a study by Ozyer et al., it was reported that the rate of those who knew that HPV causes genital warts was $14.2 \%$ and the rate of those who knew that it may cause cervical cancer was 33.3\% (24). In a study conducted in England, it was emphasized that half of the participants had a low level of knowledge (25). Moreover, in many other studies, it was also stated that the level of knowledge was not at the desired levels $(26,27)$.

In the study by McKian et al. investigating the causes of health behaviors, it was observed that one of the most effective ways of making positive changes in health behaviors is to increase the level of knowledge (28). In the light of these results, it can be speculated that the studies aiming to increase the level of knowledge have a critical role in increasing HPV vaccination.

Although there may be some factors that may positively affect the attitudes and behaviors towards the vaccine, there may also be obstacles to the formation of the behavior. The studies in the literature have shown that parents may be against HPV vaccination for personal, cultural, religious or medical reasons (29). In our study, the rate of those who did not find the HPV vaccine consistent with their religious values was $1.1 \%$. Among the parents, the rate of those who thought that the HPV vaccine would increase polygamy was $1.8 \%$. The rate of the parents with a concern of early sexual activity of their children was $1.9 \%$. In the study by Rand et al. (30) on 430 parents and 230 adolescents, it was indicated that some cultural and ethnic characteristics affect the rejection of the vaccine. The researchers have reported that taking care of the safety of the vaccine and some cultural issues may increase the rate of the vaccine. In the study by Perkins et al. (8), the reasons for vaccine rejection were reported as insufficient information (21\%), daughter's being too young (13\%), and safety problems (11\%). In the same study, it was observed that misconceptions like vaccination is not required before sexual intercourse were common.

The studies conducted not only in our country but also in many different cultures show that parents can think that 
this vaccine will cause their children to start sexual activity early $(31,32)$. However, when the longitudinal studies in the literature were reviewed, it was observed that there was no change in the sexual behaviors of immunized girls, such as sexual intercourse, number of partners, protective behaviors during sexual intercourse during the follow-up $(33,34)$. In our study, the rate of those who did not find appropriate to be vaccinated due to social pressure was $2.60 \%$. Social pressure is another factor that can be eliminated by various extensive information-oriented studies. Educational activities have an important role both in breaking negative attitudes of people in the environment and affecting vaccination behaviors of individuals.

\section{Conclusion}

In conclusion, it was found that awareness about HPV infection and vaccine was very low even in a sample with good socioeconomic level who can access health services under the most favorable conditions in our country. The rate of HPV vaccination is also very low. As part of the sexual education provided in schools, the modes of transmission of HPV should be addressed and conveyed by experts. The awareness of parents about HPV infection and vaccination should be increased and the vaccine should be administered at an early age, especially by increasing the communication between health professionals and parents.

Ethics Committe Approval: The approval for this study was obtained from Medical Research Ethics Committee of Yıldırım Beyazıt University (Decision No: 2017/25, Date: 19.09.2017).

Informed Consent: Patient consent was obtained.

Peer-review: Externally peer-reviewed.

Author Contributions: Concept - SIO; Design - PC, SIO; Supervision - SIO; Resource - PC, SIO; Data Collection and/or Processing - PC; Analysis and/or Interpretation - PC, SIO; Literature Search - PC, SIO; Writing - PC; Critical Review - SIO.

Conflict of Interest: All authors declare that they have no conflicts of interest or funding to disclose.

Financial Disclosure: The authors declared that this study has received no financial support.

\section{References}

1. Baseman JG, Koutsky LA. The epidemiology of human papilloma virus infections. J Clin Virol 2005;32:16-24. [CrossRef]

2. Bernstein HH, Bocchini JA, Diseases Col. The need to optimize adolescent immunization. Pediatrics 2017;139:e20164186. [CrossRef]

3. Borena W, Luckner-Hornischer A, Katzgraber F, Holm-von Laer D. Factors affecting HPV vaccine acceptance in west Austria: Do we need to revise the current immunization scheme? Papillomavirus Res 2016;2:173-7. [CrossRef]
4. Taebi M, Riazi H, Keshavarz Z, Afrakhteh M. Knowledge and attitude toward human papillomavirus and HPV vaccination in Iranian population: a systematic review. Asian Pac J Cancer P 2019;20:1945-9. [CrossRef]

5. Turkey Demographic and Health Survey. 2014. Available from: http:// www.hips.hacettepe.edu.tr/eng/TDHS_2013_main.report.pdf (Accessed date: 15 February 2016). [CrossRef]

6. Onan A, Özkan S, Korucuoğlu Ü, Aksakal N, Tașkıran Ç, Aygün R, et al. Knowledge on and attitude toward human papillomavirus infection and its vaccine in a Turkish subpopulation. Türkiye Klinikleri Tıp Bilimleri Dergisi 2009;29:594-8. [CrossRef]

7. Glenn BA, Tsui J, Coronado GD, Fernandez ME, Savas LS, Taylor VM, et al. Understanding HPV vaccination among Latino adolescent girls in three U.S. regions. J Imm Minor Health 2015;17:96-103. [CrossRef]

8. Perkins RB, Clark JA, Apte G, Vercruysse JL, Sumner JJ, Wall-Haas CL, et al. Missed opportunities for HPV vaccination in adolescent girls: a qualitative study. Pediatrics 2014;134:666-74. [CrossRef]

9. Reagan-Steiner S, Yankey D, Jeyarajah J, Elam-Evans LD, Singleton JA, Curtis $C R$, et al. National, regional, state, and selected local area vaccination coverage among adolescents aged 13-17 Years-United States, 2014. MMWR 2015;64(29):784-92. [CrossRef]

10. Al-Naggar RA, Bobryshev YV, Al-Jashamy K, Al-Musli M. Practice of HPV vaccine and associated factors among school girls in Melaka, Malaysia. Asian Pacific Journal of Cancer Prevention 2012;13:3835-40. [CrossRef]

11. Hayashi Y, Shimizu Y, Netsu S, Hanley S, Konno R. High HPV vaccination uptake rates for adolescent girls after regional governmental funding in Shiki City, Japan. Vaccine 2012;30:5547-50. [CrossRef]

12. Potts A, Sinka K, Love J, Gordon R, McLean S, Malcolm W, et al. High uptake of HPV immunisation in Scotland-perspectives on maximising uptake. Euro Surveill 2013;18(39):20593. [CrossRef]

13. Bowyer HL, Forster AS, Marlow LA, Waller J. Predicting human papillomavirus vaccination behaviour among adolescent girls in England: results from a prospective survey. I Fam Plann Reprod Health Care 2014;40:14-22. [CrossRef]

14. Patel H, Pcolkina K, Strazdina K, Viberga I, Sherman SM, Tincello DG, et al. Awareness of HPV infection and attitudes toward HPV vaccination among Latvian adolescents. Int J Gynaecol Obstet 2017;137:138-44. [CrossRef]

15. Choi HC, Leung GM, Woo PP, Jit M, Wu JT. Acceptability and uptake of female adolescent HPV vaccination in Hong Kong: a survey of mothers and adolescents. Vaccine 2013;32:78-84. [CrossRef]

16. Patel C, Brotherton JML, Pillsbury A, Jayasinghe S, Donovan B, Macartney $K$, and et al. The impact of 10 years of human papillomavirus (HPV) vaccination in Australia: what additional disease burden will a nonavalent vaccine prevent? Euro Surveill 2018;23:1700737. [CrossRef]

17. Fisher H, Trotter CL, Audrey S, MacDonald-Wallis K, Hickman M. Inequalities in the uptake of human papillomavirus vaccination: a systematic review and meta-analysis. Int J Epidemiol 2013;42:896-908. [CrossRef]

18. Schreiber SMS, Juul KE, Dehlendorff C, Kjær SK. Socioeconomic predictors of human papillomavirus vaccination among girls in the Danish childhood immunization program. J Adolesc Health 2015;56:402-7. [CrossRef]

19. Wong CA, Berkowitz Z, Dorell CG, Anhang Price R, Lee J, Saraiya M. Human papillomavirus vaccine uptake among 9- to 17-year-old girls: National Health Interview Survey, 2008. Cancer 201;117(24):5612-20. [CrossRef]

20. Li SL, Lau YL, Lam TH, Yip PS, Fan SY, Ip P. HPV vaccination in Hong Kong: uptake and reasons for non-vaccination amongst Chinese adolescent girls. Vaccine 2013;3:5785-8. [CrossRef] 
21. Quinn GP, Vadaparampil ST, Johns T, Alexander KA, Giuliano AR. Adolescent sexual activity and cancer risk: physicians' duty to inform? Current Medical Research and Opinion 2014;30:1827-31. [CrossRef]

22. Dempsey AF, Abraham LM, Dalton V, Ruffin M. Understanding the reasons why mothers do or do not have their adolescent daughters vaccinated against human papillomavirus. Ann Epidemiol 2009;19:531-8. [CrossRef]

23. Reiter PL, Katz ML, Paskett ED. Correlates of HPV vaccination among adolescent females from Appalachia and reasons why their parents do not intend to vaccinate. Vaccine 2013;3:3121-5. [CrossRef]

24. Ozyer S, Uzunlar O, Ozler S, Kaymak O, Baser E, Gungor T, et al. Awareness of Turkish female adolescents and young women about HPV and their attitudes towards HPV vaccination. Asian Pac J Cancer P 2013;14:4877-81. [CrossRef]

25. Bowyer HL, Marlow LA, Hibbitts S, Pollock KG, Waller J. Knowledge and awareness of HPV and the HPV vaccine among young women in the first routinely vaccinated cohort in England. Vaccine 2013;31:1051-6. [CrossRef]

26. Hoglund AT, Tyden T, Hannerfors AK, Larsson M. Knowledge of human papillomavirus and attitudes to vaccination among Swedish high school students. Int J STD AIDS 2009;20:102-7. [CrossRef]

27. Blodt S, Holmberg C, Muller-Nordhorn J, Rieckmann N. Human Papillomavirus awareness, knowledge and vaccine acceptance: a survey among 18-25 year old male and female vocational school students in Berlin, Germany. Eur J Public Health 2012;22:808-13. [CrossRef]
28. MacKian S. A review of health seeking behaviour: problems and prospects. Health Systems Development Programme, University of Manchester, Manchester 2003. [CrossRef]

29. DiAnna Kinder F. Parental Refusal of the Human Papillomavirus Vaccine. J Pediatr Health Care 2016;30(6):551-7. [CrossRef]

30. Rand CM, Schaffer SJ, Humiston SG, Albertin CS, Shone LP, Heintz EV, et al. Patient-Provider Communication and Human Papillomavirus Vaccine Acceptance. Clinical Pediatrics 2010;50:106-13. [CrossRef]

31. Brewer NT, Cuite CL, Herrington JE, Weinstein ND. Risk compensation and vaccination: can getting vaccinated cause people to engage in risky behaviors? Annals of Behavioral Medicine 2007;34:95. [CrossRef]

32. Ogilvie GS, Remple VP, Marra F, McNeil SA, Naus M, Pielak KL, et al. Parental intention to have daughters receive the human papillomavirus vaccine. CMAJ 2007;177:1506-12. [CrossRef]

33. Donken R, Tami A, Knol MJ, Lubbers K, van der Sande MAB, Nijman HW, et al. Changes in (risk) behavior and HPV knowledge among Dutch girls eligible for HPV vaccination: an observational cohort study. BMC Public Health 2018;18:837. [CrossRef]

34. Forster AS, Marlow LA, Stephenson J, Wardle J, Waller J. Human papillomavirus vaccination and sexual behaviour: cross-sectional and longitudinal surveys conducted in England. Vaccine 2012;30:4939-44. [CrossRef] 